This is the author's final, peer-reviewed manuscript as accepted for publication. The publisher-formatted version may be available through the publisher's web site or your institution's library.

\title{
Peaks of Identity in Colorado's San Juan Mountains
}

Kevin S. Blake, Kansas State University, Manhattan, KS

\section{How to cite this manuscript (APA format)}

If you make reference to this version of the manuscript, use the following citation format:

Blake, Kevin S. (1999). Peaks of Identity in Colorado's San Juan Mountains. Retrieved from http://krex.ksu.edu

\section{Published Version Information}

Citation: Blake, Kevin S. (1999). Peaks of Identity in Colorado's San Juan Mountains. Journal of Cultural Geography, Volume 18, Number 2, Spring/Summer 1999, pages 2955.

Copyright: Copyright Taylor \& Francis Group

Digital Object Identifier (DOI): DOI: 10.1080/08873639909478303

\section{Publisher's Link:}

This is an electronic version of an article published in Blake, Kevin S. (1999). Peaks of Identity in Colorado's San Juan Mountains. Journal of Cultural Geography, Volume 18, Number 2, Spring/Summer 1999, pages 29-55. Journal of Cultural Geography is available online at: http://www.informaworld.com with the open URL of your article, which would be the following address:

http://www.informaworld.com/openurl?genre=article\&issn=08873631\&volume=18\&issue $=2 \&$ spage $=29$.

This item was retrieved from the K-State Research Exchange (K-REx), the institutional repository of Kansas State University. K-REx is available at http://krex.ksu.edu 
Peaks of Identity in Colorado's San Juan Mountains

Kevin S. Blake

Published in Journal of Cultural Geography

Volume 18, Number 2, Spring/Summer 1999 
Abstract. The glaciated ranges of southwestern Colorado constituting the San Juan Mountains are culturally significant to residents and visitors. As certain mountains are imbued with meaning, they become "peaks of identity," tangible and towering symbolic landscapes representing a distinctive set of community and cultural ideals. This paper explores the symbols and themes of San Juan peaks of identity, with a focus on the mountain amenity town of Lake City and nearby Uncompahgre Peak. Uncompahgre's icon dominates mountain representations in Lake City and instantly identifies the community; its symbolism embodies aesthetics of form and elevation and the sanctity of hallowed ground. Mountain symbolism in the San Juans is mainly projected through land use and the display of icons and names on signs and government seals. Although the San Juans are sacred to the Utes and Navajos and represent a rich mining heritage, they also symbolize idealized natural scenery, landmarks of home, recreation opportunities, and spiritual renewal. Many San Juan communities identify with mountains in a generic sense, but this article focuses on the traits, variability, and depth of meaning of the mountains that are landscape signatures of community identity. 
Symbolic landscapes represent the nature of human attachment to places and the values of cultures and individuals. Studies of symbolic landscapes are often focused upon the built environment or landscapes that have been significantly modified by human agency (e.g., Meinig 1979; Rowntree and Conkey 1980; Raitz and VanDommelen 1990). Mountains are also symbolic landscapes, forming the bedrock of how some cultures perceive themselves and their relationship with their environment. The attitudes associated with high places have ranged from gloom to glory (Nicolson 1997), and many mountains throughout the world are seen as ideal recreation playgrounds. Although the San Juan Mountains of southwestern Colorado are sacred to the Navajo and Ute cultures and spiritually significant to countless other mountain mystics, the communities in the region have forged secular yet deeply symbolic identities with these peaks. Over the last century the San Juan Mountains have represented each of the five Mountainous West regional themes identified by Wyckoff and Dilsaver (1995): barriers to easy movement and communication, islands of moisture, zone of concentrated resources, area of government control, and restorative sanctuary. The appreciation of the scenery, mining wealth, and recreation opportunities of the San Juans contributes to them being a source of local, regional, and national pride.

This article explores how the San Juan Mountains have become culturally significant through the meaning and projection of their symbolism. The focus is on the mountains that are "peaks of identity," towering and tangible symbolic landscapes expressing a distinctive set of community and cultural ideals. Various symbols, such as icons (pictorial representations) on signs, are analyzed to identify the symbolic themes of the peaks of identity (Daniels and Cosgrove 1988). The article first describes the San Juan Mountain area and its historical identity, and then examines specific symbols at regional 
and local scales. The relationship of Lake City with Uncompahgre Peak (pronounced unkum-PAH-gray) is presented as a particularly strong example of a peak of identity. Next, the traits, variability, depth, and magnitude of the peak of identity concept are defined. Concluding the article is a summary of the San Juan peaks of identity and their cultural significance. With the long tradition of many San Juan towns serving as an idealized vacationland, the findings of this study are reflective of visitor and resident attitudes toward mountains.

\section{The American Alps}

The Alps -- storied monuments of poetical legendary fame -- cannot compare with these mountains in scenes of sublime beauty and awful grandeur. (George Crofutt 1885, 25)

Several rugged, high mountain ranges, each with distinct landform characteristics and names, connect to form the alpine region called the San Juan Mountains (Fig.1.). The mostly volcanic, glacially carved ranges have inspired observers to lyrical heights, earning such nicknames for the region as "fire and ice" (Chronic 1980, 218), "the American Alps" (Baars 1992, 4), and "a land of endless mountains" (Borneman and Lampert 1998, 195). The San Juans are a roughly circular uplift in the Southern Rocky Mountains geomorphic province, reaching at the greatest extent about 100 miles north to south and 120 miles east to west.

The vast majority of the San Juan Mountains formed between 35 and 25 million years ago in incredible outpourings of lava (Chronic 1980). Glacial erosion left many horns, cirques, arêtes, tarns, and U-shaped valleys; heavy snows on the over-steepened slopes are the source of countless avalanches each winter (Fig. 2.). The signature feature 
of the San Juans is its overall elevation. No other mountain range in the contiguous United States contains as much land over 10,000 feet, and 13 of Colorado's 54 Fourteeners, mountains higher than 14,000 feet, are in the range (Borneman and Lampert 1998). Through the heart of this expansive jumble of peaks winds the Continental Divide, creating a maze of watersheds with rivers draining in all directions. To the east of the divide rises the Rio Grande; to the west are major tributaries of the Colorado River system: the Lake Fork of the Gunnison, Uncompahgre, Dolores, San Miguel, San Juan, Animas, and La Plata (Griffiths 1984).

The highways in the San Juan Mountains wind over high passes to Victorian mining towns and popular recreation areas. Cattle ranches, orchards, Anasazi ruins, and booming mountain amenity towns all lie within the region. Before Anglo miners invaded these heights in the late nineteenth century, Utes dominated most of the region and Navajos frequented the southernmost parts (Baars 1992). Spain, Mexico, and the Republic of Texas claimed at one time a portion of the San Juans. The first Spanish explorer in the area was Don Juan Maria de Rivera in 1765. In 1776 two Franciscan priests, Francisco Atanasio Dominguez and Silvestre Vélez de Escalante, followed Rivera's route through the southwest portion of the San Juans in their search for an overland route to Monterey, California (Noel et al. 1994).

Treaties in 1874 and 1881 resulted in the removal of the Utes from the heart of the San Juans and the opening of the gold and silver mining districts. Four Ute bands, the Uintah, Uncompahgre, Grand River, and Yampa, relocated to the Uintah Reservation in Utah. The Weeminuche, Capote, and Mouache bands went to the Ute Mountain Reservation, headquartered at Towaoc, Colorado, and the Southern Ute Reservation, headquartered at Ignacio, Colorado (Trimble 1993). The 1882 completion of a narrow- 
gauge railroad from the Durango smelter to Silverton ore deposits initiated the mining heyday and established Durango as the primary regional center. Concurrent with the mining boom, the San Juans were discovered as a tourist paradise, especially for healthseeking visitors to hot springs in Ouray and Durango. The region's dramatic mountain vistas soon earned it the sobriquet "Switzerland of America" (Smith 1995, 110).

Following the Silver Panic of 1893, mining went through a slow decline and tourism became the region's economic pillar. In the 1940s the San Juan Mountains were described as "one of Colorado's last frontiers. . . . A few cattlemen and sheepmen live in this inhospitable land" (Writers' Program 1941, 400), and Ouray was deemed "a gloomy little town" (Lavender 1943, 3). The mining slump prompted the erection in 1959 of the Christ of the Mines statue on Anvil Mountain overlooking Silverton. A marker at the shrine states it asks "God's blessing on the mining industry."

The San Juans have been a recreation mecca for the entire twentieth century (Ormes 1951). Today over 200,000 tourists annually take the train from Durango to Silverton (Smith 1995). The San Juans are in the "New West," a region that has replaced California as America's mythmaking destination. The mountain towns of the New West represent spectacular scenery, clean air, safety, and American values. Many factors push people to migrate to the region, but the most significant pull factor is mountainous terrain (Bonfante 1993). The San Juans are an example of what Wilbur Zelinsky (1992) calls a montane pleasuring place in a voluntary region, attracting an outdoor recreation subculture in such numbers as to dominate land use.

To study the cultural meaning of the San Juans field methods were used to see what symbols are projected in the landscape. The use, ownership, and designations of mountain lands are telling indicators of their symbolism; data about these were collected primarily 
through field observations and local newspaper stories, supplemented with interviews and information on government maps. The meaning of mountain names and icons on signs and murals was documented by recording the sign location, content, and type, and photographing it for later reference (Fig. 3.). Logos, the pictorial emblems identifying organizations, are enduring symbols of authority and identity. Government logos or seals are usually widely projected on official literature, welcome and street signs, government vehicles, and public buildings. The icons on government seals are integral in creating a symbolic link between a community and its environment (Short et al. 1993). Mountain toponyms, chamber of commerce logos, newspaper mastheads, postcards, real estate advertisements, and folklore are also significant symbolic projections leading to the creation of San Juan peaks of identity. Symbols projected in the landscape are especially potent because they are visible to virtually all residents and visitors, working to forge a closer bond between mountains and people.

Data were collected from each of the highways and communities in Colorado shown in Figure 1, except for Alamosa since all of Alamosa County lies outside the San Juan Mountains. Observations were made in the 14 Colorado counties containing a portion of the San Juans, in the 29 incorporated towns and cities in these counties (South Fork and Conejos are unincorporated), and on the Ute Mountain and Southern Ute Reservations. To gather exact data on land use and place names, as well as to examine the meaning of one San Juan peak in great detail, the focus was narrowed in part of this study to Hinsdale County, its county seat of Lake City, and nearby Uncompahgre Peak. For the intensive study of Hinsdale County the field methods included regular visits in different seasons for over 10 years, hiking each of the county's five Fourteeners (Uncompahgre, Wetterhorn, Handies, Redcloud, and Sunshine), and driving most backroads. Hinsdale 
County cuts a 1,076-square mile swath through the heart of the San Juans, and Lake City is a small town balancing its diverse tourism base with a strong sense of community. Lake City is potentially on the cusp of the same tourism and population boom that has struck Telluride, Durango, Pagosa Springs, Ouray, and Ridgway in recent years (Riebsame et al. 1997). Thus, its mountain symbolism is to some extent representative of the region's past, present, and future. Uncompahgre Peak (elevation 14,309 feet) is the highest San Juan summit, and its distinctive shape makes it an easily recognizable icon.

Every county on the western half of the San Juans is at least $80 \%$ non-Hispanic white, with small percentages of Hispanics and American Indians; Hinsdale County is $99 \%$ non-Hispanic white. The southeastern counties (Archuleta, Conejos, Rio Grande, and Saguache) are ethnically more diverse, with Hispanics constituting from about $25 \%$ in Archuleta County (county seat Pagosa Springs) to 60\% in Conejos County (county seat Conejos), and the remainder mostly non-Hispanic white (U.S. Bureau of the Census 1992). Mountain place names reflect the Spanish and Ute heritage in Hinsdale County (Table 1.). Although the numbers of Spanish and Ute names are relatively few, they exist for some of the most prominent features in the region. American Indians had many more names for rivers than peaks, so the names of mountains are often transferred from rivers (Stewart 1945). Uncompahgre Peak and the San Juan Mountains both take their name from rivers. Uncompahgre is a corruption of a Ute name recorded by Dominguez and Escalante; it roughly translates as "red lake," named for a reddish hot spring near the river's source (Baars 1992). In the late eighteenth century the San Juan Mountains were called Sierra de la Grulla (Mountains of the Cranes) (Helphand 1991), but eventually the name given by Dominguez and Escalante to the San Juan River was transferred to the mountains. The San Miguel Range and Pagosa Peak names are also transferred from a river and a 
spring, whereas the Cochetopa (Buffalo Passing) Hills and La Garita (The Lookout) Range are associative names relating to a wildlife trail and Indian smoke signals from a high point (Bright 1993).

Anglo miners and surveyors are responsible for the majority of Hinsdale County names, with descriptive names the runaway favorite. The one incident name, Cannibal Plateau, is noteworthy as a landmark event in San Juan history in which Alferd Packer "served his fellow man" (McTighe 1989, 245). In the winter of 1873-1874, Packer and five companions attempted a traverse of the San Juans, but only Packer emerged. He admitted to killing at least one comrade and cannibalizing all of them near the present site of Lake City. The notoriety of his capture, escape, re-capture, trial, conviction, and eventual pardon riveted national attention on the San Juans and is a celebrated part of Lake City lore.

\section{Representing Nature}

In them are the places of your recreation, the material for your houses, the summer pastures of your flocks. They are the backdrop of all your daydreams. (David Lavender 1943, vi)

Mountainous scenes are never out of sight or mind in the San Juans, and natural symbols are common in the region's signage. Comparing the actual mountain vistas with representations helps to understand what peaks are symbolic and what mountain traits are favored for idealization (Weightman 1981). What entity places the signs and whether the names and icons are generic (general or stylized) or signature (exact) representations affect the power of a representation. Governments and chambers of commerce lead in the use of mountain names and icons on signs, followed closely by retail (mostly gift shops), lodging, 
and real estate establishments. This hierarchy indicates mountains have meaning to residents and visitors alike. Generic representations are more frequent than signature representations in the retail and lodging businesses serving tourists, but the governments and chambers, with a larger constituency than the other establishment types, more often project signature peak names and icons, thereby contributing to the creation of a peak of identity.

The combination of the mountain icon with other icons establishes a theme of symbolism. Natural mountain scenery is a primary theme in $58 \%$ of government seals. Representations of local built environment features (30\%), such as historic structures or major tourist attractions, and economic activities (21\%), such as mining and agriculture, are the second and third most common themes. The above percentages add to more than 100 since the same logo can have more than one main theme. The Lake City seal, for example, projects natural and economic images (Fig. 4.).

Some peaks are icons for more than one government, and the depth of meaning varies. The La Plata Mountains appear on three seals (Dolores, Durango, and La Plata County) always as stylized sharp and exaggerated peaks. Sleeping Ute Mountain is on two seals (Montezuma County and Ute Mountain Reservation), but the montage of icons lessens its visibility on the seals. Uncompahgre Peak is on two seals (Hinsdale County and Lake City) as a signature peak, represented almost exactly as it appears in reality. The effort taken to ensure precise representation indicates local pride in the peak's aesthetics and potentially even greater depths of meaning.

Table 2 summarizes the mountain representations on government seals, chamber of commerce logos, and newspaper mastheads. Of the 42 San Juan governmental entities, $90 \%$ have a seal with any icon, $71 \%$ have a seal with mountains, and $40 \%$ have a seal with 
a signature peak. The seal designer may often intend for generic ranges to represent local mountains, but they were tallied as generic if the detail needed to signify a particular peak is lacking. When there was any doubt whether an icon was generic or signature, several government employees were questioned. Of the 42 governments, $26 \%$ have a seal with landscape projection; all of these seals feature mountains, indicating the importance of peaks as visual icons. The projection of a symbol, such as on a welcome sign, increases the familiarity of the mountain and links it more closely with community identity.

Chamber of commerce logos and newspaper mastheads feature mountain icons less frequently than do government seals. Natural scenery is nevertheless the dominant theme, indicating its prime appeal to residents and tourists. Four of the signature peaks on chamber logos, Uncompahgre Peak (Lake City-Hinsdale County), Mount Abrams (Ouray), Pagosa Peak (Pagosa Springs), and Ajax Peak (Telluride), are also represented on government seals. The landscape projection of most chamber logos is minor, if present at all, except for the aggressive signage projection of Mount Abrams by the Ouray Chamber. The icon of the Inspiration Point cliffs on Mammoth Mountain at the north edge of Creede is the only one on both a newspaper masthead and a chamber logo. Mesa Verde is the only eminence to be on both a newspaper masthead and a government seal, albeit for different entities (Mancos and Cortez). Mining is a major theme on six of the newspaper mastheads, and three of the designs show a scene from a historical business district. Seven newspaper mastheads reflect recent cultural tastes and economic conditions with a mountainous scenery theme. Government, chamber, or newspaper symbols featuring mountains primarily represent the heights as the centerpiece of pristine natural scenery, an ideal restorative sanctuary for either residents or tourists. 


\section{A Diamond in the Rough}

... we could see the whole south slope of Uncompahgre. It is a peculiarly

shaped mountain of strong individuality, carved from the horizontal

volcanic layers that produce successive cliffs separated by debris slopes.

There is a great precipice on the north -- one of the most remarkable

in the state -- which drops sharply from the topmost rock and actually

overhangs for some distance. (William Cooper 1908, quoted in Pickering 1993, 13)

About 700 years ago a tremendous mass of decomposed volcanic rock slumped from the south slope of Mesa Seco (Dry Mesa). The mass movement dammed the river four miles away, creating Lake San Cristobal, the second largest natural lake in Colorado. Subsequently, the river was named the Lake Fork of the Gunnison and the closest town Lake City. The colorful and hummocky Slumgullion Earthflow, named for the miner stew containing a bit of everything, is still moving a few feet per year (Chronic 1980). Founded in 1874 at the confluence of the Lake Fork and Henson Creek, Lake City (elevation 8,671 feet) quickly reached its zenith two years later as Colorado's preeminent Western Slope mining and stage freighting town. After a mining depression in the 1880 s, the early 1890 s brought a last mining boom with the arrival of a railroad and the production of silver and lead ores (Houston 1990).

Hinsdale County is $97 \%$ public land. Portions of four national forests lie within its borders: Gunnison, Uncompahgre, Rio Grande, and San Juan. Likewise, portions of four wilderness areas are in Hinsdale County: Uncompahgre, Weminuche, and La Garita, each administered by the Forest Service, and the Powderhorn administered by the Bureau of Land Management (BLM). The non-wilderness BLM land in the Lake City area has the 
highest concentration of historic mining relics and backroads in the county. The primary uses of private land in the county are ranching, mining, commercial, and residential (Wilcox 1995).

Lake City, the only town in Hinsdale County, is today a National Historic District and a summer vacation haven, with most businesses catering to the tourist need for lodging, food, recreation, and gift shopping (Fig. 5.). Lake City is at the terminus of two National Scenic Byways, the west end of the Silver Thread on Colorado State Highway 149, and the east end of the Alpine Loop, a network of primitive roads on BLM land connecting Lake City with Ouray and Silverton. The year-round population of Lake City increased nearly 25\%, to 581, from 1990-1995 (Pierce 1995). Lake City’s small-town character is evoked by its four church buildings, three gas stations, two grocery stores (only one in winter), one automatic teller machine, and zero national chain businesses.

About eight miles northwestward of Lake City atop the Uncompahgre Wilderness is the massive anvil shape of Uncompahgre Peak (Fig. 6.). The mountain is formed of crumbling igneous rocks, and its high meadows provide summer pasturage for thousands of domestic sheep. Over a century ago this peak was thought to be the highest in the Rockies; today it ranks sixth. The appreciation of Uncompahgre's aesthetic value has been strong since the days of first settlement when it was seen as the preeminent peak in the area with scenery "among the grandest on the Continent" (Silver World 1875, 3). Uncompahgre is Lake City's peak of identity with projected symbolism in signs, logos, postcards, toponyms, and land use. Uncompahgre Peak is the local leader in signature symbols on signs with 12, compared to four for the runner-up, Round Top Mountain.

Uncompahgre's iconography began in 1881 with the adoption of the town seal (Pierce 1995) (Fig. 4.). Many other local entities, including Hinsdale County, have 
borrowed the iconic perspective of the town seal, indicating in part the symbolic power accruing to a logo with longstanding use. The local chamber adds to the representations of Uncompahgre Peak as a community symbol with its logo of the peak towering behind the Silver Street business row. Visitor brochures, business window stickers, and a special Visa credit card project the chamber logo. In 1991, the chamber's promotional slogan was "A Diamond in the Rough," with Uncompahgre Peak representing the "rough" wilderness and Lake City the "diamond" (Fig. 7.). At least 15 local businesses plus the public library use the Uncompahgre icon on signs and printed materials (Fig. 3.). Hall Realty, for example, uses Uncompahgre Peak to symbolize their Lake City business and Bristol Peak to represent their Creede activities. The logo of Cannibal Outdoors, an outdoor recreation guide and outfitter, combines the main historical and natural icons of Lake City by depicting Alferd Packer holding a paddle in front of Uncompahgre.

Normally a peak of identity is visible from a community, but Uncompahgre Peak is not visible in Lake City. Nevertheless, the exact same perspective, looking northwestward, is almost always the symbolic icon of Uncompahgre because of the dramatic view from Slumgullion Pass leading into town from the southeast on Highway 149. Uncompahgre, 14 miles distant, rises like a monstrous ship's prow to loom over the San Juans. Without the view from the pass Uncompahgre's icon would be far less recognizable, and the peak would be less meaningful. The Lake City signs with signature icons of Round Top Mountain that echo or duplicate the vista toward the south end of town also exemplify the importance of visibility in San Juan symbolism.

The accessibility of Uncompahgre has been key in the close association of residents and visitors with the peak. The depth of Uncompahgre's meaning to long-time residents and visitors is evinced by many claims that if a person climbs only one mountain in their 
life, it's Uncompahgre (Van Wormer 1995; Coursey 1997). Starting in the 1870s, ascents to the summit have been commonplace, with great notoriety attached to efforts to raise a flagpole on top or ride a bicycle to the top. Today generations of family members will gather to climb the mountain together in a pilgrimage of family and community values (Houston 1997). The peak is a symbol of hallowed ground, both in terms of its frequent use for the ceremonial scattering of a loved one's cremains (Hendryx 1995) and its icon on the Lake City Cemetery gate. Furthermore, the titles of a local multi-media production about life in Lake City and a local guidebook are "In the Shadow of Uncompahgre." Uncompahgre Peak's symbolism has accrued over many decades and is centered on spiritual renewal and a landmark of home.

\section{Glistening Landmarks}

Thousands of tired, nerve-shaken, overcivilized people are beginning to find out that going to the mountains is going home; that wildness is a necessity; and that mountain parks and reservations are useful not only as fountains of timber and irrigating rivers, but as fountains of life. (John Muir 1898, quoted in Fox 1981, 116)

The recent boom of amenity migrants moving to the San Juan Mountains causes concern over sprawling land-use conversion and what sort of place identity exists (Riebsame et al. 1996; Ringholz 1996). The peaks of identity in the San Juan Mountains symbolically express community ideals, including an accentuated regard for aesthetics. Peaks of identity are scenic landmarks, but mountain symbolism associated with a scenic landmark is not in any sense superficial; it is a function of deep-seated cultural attitudes toward aesthetics of natural landscapes. A peak of identity that is a scenic landmark is 
more than idealized scenery, it is a landscape signature of home. Uncompahgre Peak's unique icon, for example, instantly represents Lake City to town residents (Hendryx 1995). Table 3 summarizes the peaks of identity in the San Juan Mountains. In addition to the scenic landmark of home symbolism, the representation of the mountain as a recreation haven, or a place of spiritual renewal through recreation, is a second key theme of San Juan peaks of identity. Pride in mining heritage is a third major symbolic theme. Place identity centered on nearby mountains is manifest through the combination of symbolic projections, not simply one projection. The echoing of symbolism throughout several media is further evidence of broad-based feelings toward mountain landscapes.

The depth of meaning of each peak of identity varies; stronger examples include Lake City, Pagosa Springs, and Silverton, and a weaker example is Montrose. Signature icons of Pagosa Peak's (12,640 feet) conspicuous horn appear on an impressive array of materials in Pagosa Springs, with the aesthetic qualities of the peak and its opportunities for high-elevation hiking often touted. Kendall Mountain (13,066 feet) is Silverton's peak of identity, in part because residents are always aware of the avalanche tracks leading straight into town (Fig. 8.). Kendall Mountain is the focus of the town's recreation with a park and small ski run at the base and a road leading to the top used in the Kendall Mountain Run, the major summer event. The brilliant winter afternoon reflection off its snowy western face also contributes to Kendall being the dominant local landmark (Norman 1995). Mount Sneffels (14,150 feet) is represented on Montrose business and welcome signs, but the Black Canyon of the Gunnison, a closer landmark and a significant tourist attraction, competes for the city's projected landscape identity.

Several communities have more than one peak of identity, and the reasons for this relate to visibility, proximity, and land use. With its location on the periphery of the San 
Juans, Cortez has wide-open vistas in all directions. Mesa Verde brings the most visitors to town and the often-snowy La Platas are the highest and craggiest local peaks, but even more deeply symbolic is Sleeping Ute Mountain's recognizable shape dominating the southwestern skyline. Sleeping Ute Mountain is associated with multiculturalism in murals, a scenic icon of home in business signs, real estate advertisements, and the county seal, and sacred land to the nearby Ute Mountain Utes. Furthermore, local folklore highlights its creation legend.

The same mountain may be a peak of identity for more than one community, indicating an unusual combination of symbolic qualities. The grand, serrated, north-facing escarpment of the Sneffels Range located southwest of Ridgway is visually so commanding it is surprising to find another peak of identity for any nearby community. Mount Abrams (12,801 feet), however, is also a peak of identity for Ouray. It achieves this distinction because most traffic enters Ouray from the northwest along the Uncompahgre River, and the sharp peak of Mount Abrams four miles southeast of town perfectly frames the southern terminus of the image-defining vista.

Cathedral-like Mount Sneffels with its dramatic radiating arêtes and rock glaciers may be closer than any other mountain to being a signature peak for the entire San Juans (Fig. 9.). National advertisements feature Mount Sneffels far more often than any other San Juan peak; it well represents the soaring heights, mining heritage, and rugged form of the San Juans. Sneffels also has many of the traits contributing to the image of an ideal mountain landscape: a valley perspective, upthrust and jagged peaks, evidence of glaciation, interconnecting ridges, lakes and streams, snow cover much of the year, the presence of cultural features in the foreground, and accessibility (Price 1986). The heart of the Sneffels Range can be accessed via a combination of backroads and trails from either 
the north or the southeast. Although most views of Sneffels appear to encompass only natural features, some views are available with such cultural features as mining relics, fences, roads, homes, and the reservoir at Ridgway State Park. Adding to the identification of Sneffels with the entire region is the long-range visibility of the peak and its location astride the popular San Juan Skyway National Scenic Byway, the 236-mile highway loop connecting Cortez, Telluride, Ouray, and Durango (Thompson 1994). By comparison, the La Plata Mountains are peaks of identity for two communities and include a sacred Navajo summit (Hesperus Peak, 13,232 feet), but they lack the distinctive shape and great height of Mount Sneffels to be a regional icon.

Another San Juan peak of identity is the three talus-covered summits on the edge of the Silverton caldera constituting Red Mountain (the highest elevation is 12,890 feet) (Fig. 10.). Located about halfway between Ouray and Silverton at Red Mountain Pass, Red Mountain is unusual because it is the peak of identity for a district of the San Juans -- a portion of the San Juan Skyway called the Million Dollar Highway (U.S. Highway 550 from Silverton to Ouray). Red Mountain is famous because of its bright color caused by oxidation of iron-bearing minerals and because it marks the location of rich silver-copper and silver-lead mines. The color of the peaks is so striking that Ernest Ingersoll, a nineteenth-century travel writer for Harper's Weekly, called them "gaudier than a cardinal's hat" (Gregory 1989, 83). Postcards and guidebooks are primarily responsible for the projection of peaks of identity for the communities and tourists on the San Juan Skyway. Distinctive Lizard Head (13,113 feet), a severely eroded volcanic neck located southwest of Telluride along State Highway 145 in the San Miguel Mountains, is a third San Juan Skyway peak of identity. 
The landform traits leading to a peak becoming closely associated with a community are, in declining importance, distinctive shape, bright color, great height, and long-lasting snow cover. The aspects of the relative location of a mountain to a community are also critical in establishing a deeply symbolic link; in declining importance these are visibility, proximity, accessibility, and isolation from other peaks. The long-range visibility of the Sneffels Range expands its symbolic reach farther afield than Uncompahgre. Although Uncompahgre Peak's iconic potential is bolstered by its height and shape, it suffers from its limited visibility. The far-flung symbolism of Mount Sneffels, however, diminishes the deep and proprietary symbolic connection of Mount Sneffels with any particular community. Although Mount Sneffels is potentially a signature peak of the entire San Juans, it is absent from any government seals or chamber logos. In contrast, Uncompahgre Peak has a multi-faceted and dominant meaning projected in the Lake City landscape.

By no means are peaks of identity exclusive to the San Juan Mountains; instead the close relationship of the region's communities and peaks illustrates how the multiple meanings of mountains worldwide combine to make them culturally significant landscapes. A few other well-known examples of what this article defines as peaks of identity include Mount Fuji in Japan, Mount Rainier in Washington, Pikes Peak in Colorado, Popocatépetl and Iztaccíhuatl in Mexico, and the Matterhorn in Switzerland. The religious significance, great visibility, and intensive use by pilgrims and tourists of the graceful composite volcanic cone of Mount Fuji result in this summit representing Japanese cultural values. Mount Rainier dominates western Washington to such an extent that it has poetically been termed "the mountain that was God" and, more simply, "the mountain," as though such a grand dormant volcano needed no further identification 
(Bernbaum 1990). Pikes Peak has undergone continual re-definition as a peak of identity, including roles as a gold rush landmark and a recreation mecca for Colorado Springs. Popocatépetl and Iztaccíhuatl, the "smoking mountain" and "white woman" volcanoes of Aztec lore, have been revered for centuries in the cultural hearth of Mexico as peaks of identity for Tenochtilán and Mexico City. Few mountains, however, have more stirred the imagination, especially among climbers and alpine tourists, than the sheer slopes of the Matterhorn jutting above Zermatt, Switzerland. Although not the highest or most difficult to climb peak in the Alps, the Matterhorn nevertheless stands as a peak of identity for the entire range, illustrating the importance of tourism and aesthetics in mountain symbolism. Mountains are the most prominent physical landform of southwestern Colorado, yet the symbolism of the San Juan Mountains makes them cornerstones of community identity. The San Juans are cultural landscapes with multiple themes of meaning, including scenic landmarks of home, mining heritage, recreation activities, spiritual renewal, and hallowed ground. The symbolic summits of the San Juans demonstrate how the physical characteristics of mountain landforms, the relative location of peaks to each other and to settlements, and community spirit all work together to create peaks of identity. 


\section{Acknowledgments}

The author gratefully acknowledges the comments on an earlier draft by Daniel D. Arreola, William L. Graf, Martin J. Pasqualetti, and Frederick R. Steiner, and the cartographic work by Barbara Trapido-Lurie. 


\section{References}

Baars, Donald L. 1992. The American Alps: The San Juan Mountains of Southwest Colorado. Albuquerque: University of New Mexico Press.

Bernbaum, Edwin. 1990. Sacred Mountains of the World. San Francisco: Sierra Club Books.

Biedermann, Hans. 1994. Dictionary of Symbolism: Cultural Icons and the Meanings Behind Them. Translated by James Hulbert. New York: Penguin.

Bonfante, Jordan. 1993. Sky’s the Limit. Time. 6 September: 20-26.

Borneman, Walter R., and Lyndon J. Lampert. 1998. A Climbing Guide to Colorado's Fourteeners. $3^{\text {rd }}$ ed. Boulder: Pruett.

Bright, William. 1993. Colorado Place Names. Boulder: Johnson.

Chronic, Halka. 1980. Roadside Geology of Colorado. Missoula: Mountain Press.

Coursey, Joshua. 1997. Owner, Happy Days, and Writer, Lake City Silver World. Conversation with author. 23 July.

Croffut, George A. [1885] 1981. Crofutt's Grip-Sack Guide of Colorado: 1885 Edition. Boulder: Johnson.

Daniels, Stephen, and Denis Cosgrove, (eds.). 1988. The Iconography of Landscape: Essays of the Symbolic Representation, Design, and Use of Past Environments. Cambridge: Cambridge University Press.

Fox, Stephen R. 1981. John Muir and His Legacy: The American Conservation Movement. Boston: Little, Brown.

Gregory, Marvin. 1989. Mountain Mysteries: The Ouray Odyssey. Rev. ed. Ouray, $\mathrm{CO}$ : Wayfinder.

Griffiths, Thomas M. 1984. San Juan Country. Boulder: Pruett. 
Helphand, Kenneth I. 1991. Colorado: Visions of an American Landscape. Niwot, CO: Roberts Rinehart.

Hendryx, Kelli M. 1995. Broker Associate, Hall Realty, Lake City, CO. Conversation with author. 7 November.

Houston, Grant. 1990. Lake City Reflections. Lake City, CO: Grant Houston. . 1997. Editor and Publisher, Lake City Silver World, Lake City, CO.

Conversation with author. 23 July.

Julyan, Robert H. 1984. Mountain Names. Seattle: The Mountaineers.

Lavender, David. 1943. One Man’s West. Garden City, New York: Doubleday, Doran.

McTighe, James. 1989. Roadside History of Colorado. Rev. ed. Boulder: Johnson.

Meinig, D.W., (ed.) 1979. Symbolic Landscapes: Models of American Community. In The Interpretation of Ordinary Landscapes: Geographical Essays, 164-192. New York: Oxford University Press.

Nicolson, Marjorie H. 1997. Mountain Gloom and Mountain Glory: The Development of the Aesthetics of the Infinite. Weyerhaeuser Environmental Classics Series. Seattle: University of Washington Press.

Noel, Thomas J., Paul F. Mahoney, and Richard E. Stevens. 1994. Historical Atlas of Colorado. Norman: University of Oklahoma Press.

Norman, Bill. 1995. San Juan County Administrator, Silverton, CO. Conversation with author. 6 November.

Ormes, Robert M. 1951. Colorado's Friendly Topland. National Geographic. 50(2): $187-214$.

Pickering, James H. 1993. Adventuring in Colorado’s San Juans, 1908: William Cooper's Calamitous Mountain Trek. Colorado Heritage. Summer: 2-15. 
Pierce, Michelle. 1995. Town Clerk and Administrator, Lake City, CO. Conversation with author. 7 November.

Price, Larry W. 1986. Images of Mountains: A Search for the Ideal. Yearbook of the Association of Pacific Coast Geographers. 48: 7-40.

Raitz, Karl , and Dorn VanDommelen. 1990. Creating the Landscape Symbol Vocabulary for a Regional Image: The Case of the Kentucky Bluegrass. Landscape Journal. 9(2) 109-121

Riebsame, William E., Hannah Gosnell, and David M. Theobald. 1996. Land Use and Landscape Change in the Colorado Mountains I: Theory, Scale, and Pattern. Mountain Research and Development. 16(4): 395-405. , (eds.). 1997. Atlas of the New West: Portrait of a Changing Region. New York: W.W. Norton.

Ringholz, Raye C. 1996. Paradise Paved: The Challenge of Growth in the New West. Salt Lake City: University of Utah Press.

Rowntree, Lester B., and Margaret W. Conkey. 1980. Symbolism and the Cultural Landscape. Annals of the Association of American Geographers. 70(4): 459474.

Short, J.R., L.M. Benton, W.B. Luce, and J. Walton. 1993. Reconstructing the Image of an Industrial City. Annals of the Association of American Geographers. 83(2): 207-224.

Silver World. 1875. Lake City: Its Situation, Surroundings, and Prospects. 19 June: 3. Smith, Duane A. 1995. "A Country of Tremendous Mountains": Opening the Colorado San Juans, 1870-1910. In The Mountainous West: Explorations in Historical 
Geography, edited by William Wyckoff and Lary M. Dilsaver, 92-113. Lincoln: University of Nebraska Press.

Stewart, George R. 1945. Names on the Land. New York: Random House.

Thompson, Ian. 1994. A Historical Touring Guide to the San Juan Skyway. Durango: Fort Lewis College.

Trimble, Stephen. 1993. The People: Indians of the American Southwest. Santa Fe: School of American Research Press.

U.S. Bureau of the Census. 1992. Census of Population and Housing. Summary Tape File 1A, 1990, CD-ROM. Washington, D.C.: U.S. Government Printing Office. Van Wormer, Don. 1995. Hinsdale County Executive Assistant, Lake City, CO. Conversation with author. 7 November.

Weightman, Barbara A. 1981. Arcadia in Suburbia: Orange County, California. Journal of Cultural Geography. 2(1): 55-69.

Wilcox, Amy B. 1995. Hinsdale County Assessor, Lake City, CO. Conversation with author. 7 November.

Writers' Program of the Works Progress Administration. 1941. Colorado: A Guide to the Highest State. American Guide Series. New York: Hastings.

Wyckoff, William, and Lary M. Dilsaver, (eds.). 1995. The Mountainous West: Explorations in Historical Geography. Lincoln: University of Nebraska Press.

Zelinsky, Wilbur. 1992. The Cultural Geography of the United States: A Revised Edition. Englewood Cliffs: Prentice Hall. 
Table 1. Hinsdale County Mountain Place Name Typology

\begin{tabular}{|c|c|c|c|c|c|}
\hline \multirow[b]{2}{*}{ Type } & \multirow[b]{2}{*}{ Example } & \multicolumn{3}{|c|}{ Language } & \multirow[b]{2}{*}{$\begin{array}{c}\text { Total } \\
(\mathrm{n}=68)\end{array}$} \\
\hline & & $\begin{array}{l}\text { English } \\
(\mathrm{n}=57)\end{array}$ & $\begin{array}{c}\text { Spanish } \\
(\mathrm{n}=7)\end{array}$ & $\begin{array}{l}\text { Ute } \\
(n=4)\end{array}$ & \\
\hline Descriptive & Courthouse Mountain & $25(44 \%)$ & $2(29 \%)$ & - & $27(40 \%)$ \\
\hline Transfer & Uncompahgre Peak & $10(18 \%)$ & $3(43 \%)$ & $4(100 \%)$ & $17(25 \%)$ \\
\hline Associative & Jarosa Mesa & $13(23 \%)$ & $2(29 \%)$ & - & $15(22 \%)$ \\
\hline Commemorative & Handies Peak & $8(14 \%)$ & - & - & $8(12 \%)$ \\
\hline Incident & Cannibal Plateau & $1(2 \%)$ & - & - & $1(1 \%)$ \\
\hline
\end{tabular}

Source: Mountainous landform names within Hinsdale County were categorized from three BLM surface management maps (Durango, Montrose, Silverton) and three National Forest maps (Gunnison Basin, Rio Grande, San Juan). Jarosa is Spanish for "Willow ." Names such as "Chief" and "Squaw" are categorized as English, not Ute. Some names were categorized using Bright 1993. Typology developed after Stewart 1945 and Julyan 1984. 
Table 2. Mountain Icons in the San Juan Mountains

\begin{tabular}{lcccccc}
\hline Entity & Any Icon & $\begin{array}{c}\text { Mountain } \\
\text { Icons }\end{array}$ & $\begin{array}{c}\text { Signature } \\
\text { Peak Icons }\end{array}$ & $\begin{array}{c}\text { Logos with } \\
\text { Landscape } \\
\text { Projection }\end{array}$ & $\begin{array}{c}\text { Mountain Logos } \\
\text { with Landscape } \\
\text { Projection }\end{array}$ & $\begin{array}{c}\text { Major } \\
\text { Themes }\end{array}$ \\
\hline $\begin{array}{l}\text { Government } \\
(\mathrm{n}=42)\end{array}$ & $38(90 \%)$ & $30(71 \%)$ & $17(40 \%)$ & $11(26 \%)$ & $11(26 \%)$ & $\begin{array}{c}\text { natural } \\
\text { scenery }\end{array}$ \\
$\begin{array}{l}\text { Chamber of } \\
\begin{array}{l}\text { Commerce } \\
(\mathrm{n}=16)\end{array}\end{array}$ & $15(94 \%)$ & $10(63 \%)$ & $5(31 \%)$ & $8(50 \%)$ & $5(31 \%)$ & natural \\
scenery
\end{tabular}

Source: Field collection and observation. Landscape projection data for newspaper mastheads were not gathered because mastheads are rarely visible in the landscape. 
Table 3. Peaks of Identity in the San Juan Mountains

\begin{tabular}{|c|c|c|c|}
\hline Community & Peak of Identity & Theme of Symbolism & Type of Projection \\
\hline Cortez-1 & $\begin{array}{l}\text { Sleeping Ute } \\
\text { Mountain }\end{array}$ & $\begin{array}{c}\text { multiculturalism; landmark of } \\
\text { legend }\end{array}$ & $\begin{array}{c}\text { murals; bus. names \& icons; realty } \\
\text { ads; county logo }\end{array}$ \\
\hline Cortez-2 & Mesa Verde & $\begin{array}{l}\text { historic landmark; world-class } \\
\text { tourist site }\end{array}$ & $\begin{array}{l}\text { welcome sign; mural; bus. names } \\
\text { \& icons; realty ads; city logo }\end{array}$ \\
\hline Cortez-3 & La Plata Mts. & $\begin{array}{c}\text { sacred boundary of Navajo; scenic } \\
\text { landmark }\end{array}$ & subdivision name; realty ads \\
\hline Creede & Inspiration Point & mining heritage & chamber logo; bus. icons \\
\hline Del Norte & "D" Mountain & pride in hillside letter & town logo \& signs; welcome sign \\
\hline Durango & La Plata Mountains & scenic landmark; mining heritage & $\begin{array}{c}\text { govt. } \operatorname{logos} \& \text { sign; bus. icons; } \\
\text { realty ads }\end{array}$ \\
\hline Lake City & Uncompahgre Peak & $\begin{array}{l}\text { scenic landmark; pride in height; } \\
\text { spiritual renewal by hiking; } \\
\text { sanctified eternal resting place }\end{array}$ & $\begin{array}{l}\text { govt. logos; chamber logo; } \\
\text { business icons; t-shirts; } \\
\text { mural; land use; postcard }\end{array}$ \\
\hline Montrose & Mount Sneffels & scenic landmark & $\begin{array}{l}\text { bus. icons; welcome signs; } \\
\text { newspaper masthead }\end{array}$ \\
\hline Norwood & Lone Cone & recreation haven; scenic landmark & chamber icon; realty ads; land use \\
\hline Ouray-1 & Mount Abrams & scenic landmark & $\begin{array}{l}\text { county logo; chamber logo \& } \\
\text { signs; postcards; bus. icons }\end{array}$ \\
\hline Ouray-2 & Mount Sneffels & $\begin{array}{l}\text { pride in height; scenic landmark; } \\
\text { mining heritage }\end{array}$ & bus. $\log o s / a d s ;$ realty ads \\
\hline $\begin{array}{l}\text { Pagosa } \\
\text { Springs }\end{array}$ & Pagosa Peak & scenic landmark; recreation haven & $\begin{array}{l}\text { county logo; postcards; bus. icons; } \\
\text { chamber logo; land use; realty ads }\end{array}$ \\
\hline Ridgway-1 & $\begin{array}{l}\text { Chimney-Courthouse } \\
\text { ridge }\end{array}$ & scenic landmark & $\begin{array}{l}\text { welcome signs; town logo; bus. } \\
\text { logo; realty ads }\end{array}$ \\
\hline Ridgway-2 & Mount Sneffels & recreation haven; scenic landmark & $\begin{array}{l}\text { bus. name \& icons; realty ads; } \\
\text { newspaper masthead }\end{array}$ \\
\hline $\begin{array}{l}\text { San Juan } \\
\text { Skyway-1 }\end{array}$ & Red Mountain & mining heritage; scenic landmark & $\begin{array}{l}\text { postcards; highway pass name; } \\
\text { guidebooks }\end{array}$ \\
\hline $\begin{array}{l}\text { San Juan } \\
\text { Skyway-2 }\end{array}$ & Mount Sneffels & scenic landmark; ideal homesite & postcards; realty ads \\
\hline $\begin{array}{l}\text { San Juan } \\
\text { Skyway-3 }\end{array}$ & Lizard Head & $\begin{array}{l}\text { scenic landmark; climbing } \\
\text { challenge }\end{array}$ & $\begin{array}{l}\text { postcards; highway pass name; } \\
\text { guidebooks }\end{array}$ \\
\hline Silverton & Kendall Mountain & $\begin{array}{l}\text { spectacular avalanches; town } \\
\text { recreation; scenic landmark }\end{array}$ & $\begin{array}{l}\text { land use; business icon; postcard; } \\
\text { masthead }\end{array}$ \\
\hline Telluride & Ajax Peak & scenic landmark; mining heritage & $\begin{array}{l}\text { postcards; town signs; bus. icons; } \\
\text { realty ads; chamber logo }\end{array}$ \\
\hline Ute Mountain & $\begin{array}{l}\text { Sleeping Ute } \\
\text { Mountain }\end{array}$ & $\begin{array}{l}\text { spiritual renewal; sacred warrior \& } \\
\text { rain provider }\end{array}$ & $\begin{array}{l}\text { welcome billboard; Ute seal; } \\
\text { casino name \& icon; folklore }\end{array}$ \\
\hline
\end{tabular}

Source: Compiled by author based on analysis of symbolic representations. Communities with more than one peak of identity have a number following the name, and the mountains are ranked according to the strongest symbolism based on the number, type, and theme of symbols. "Projection" column shows the representations evincing the peak of identity designation. The absence of a community from this table means that although its residents may identify with mountains, a single peak or range does not significantly stand symbolically apart from others. 


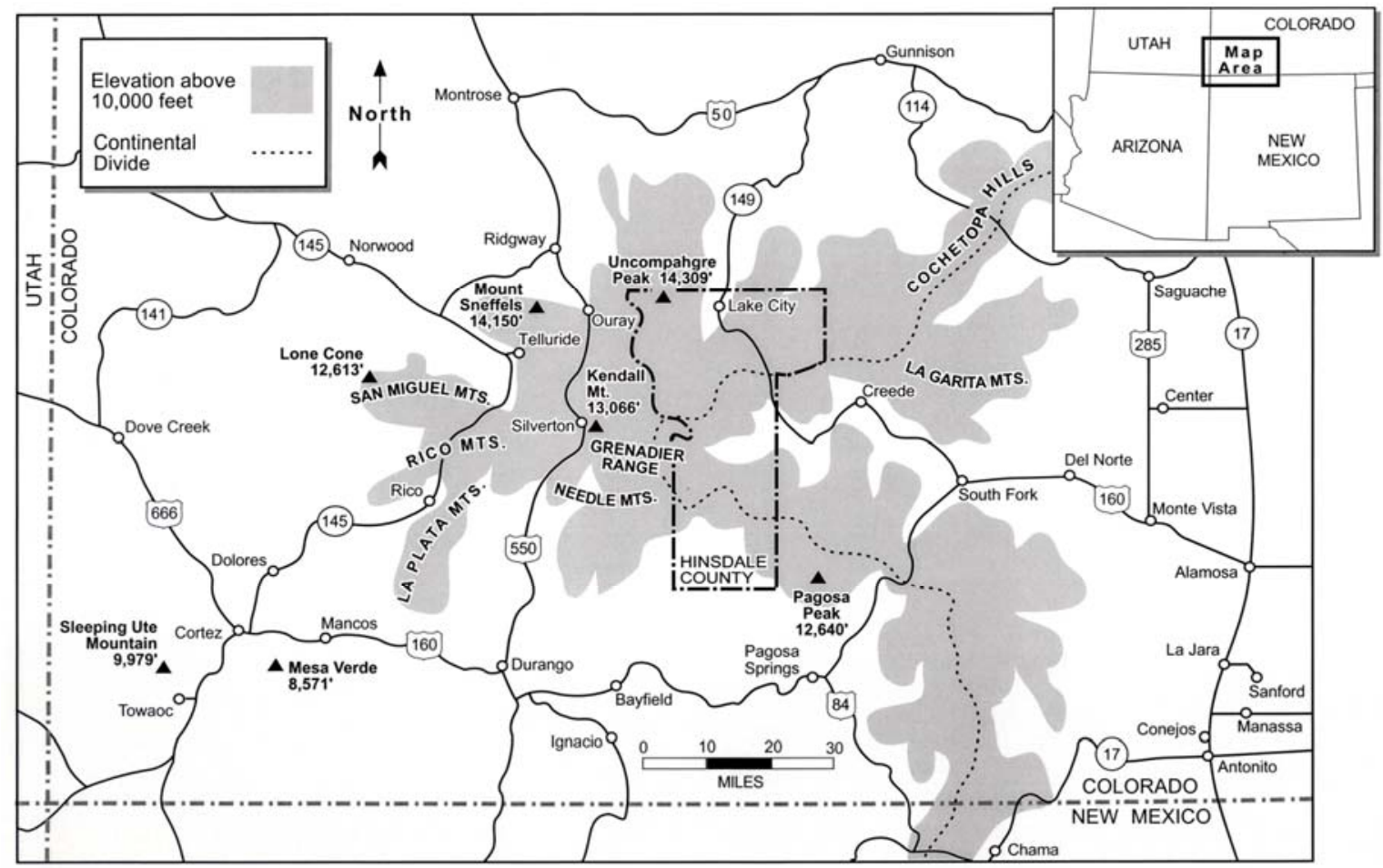

Fig. 1. The San Juan Mountains region. 


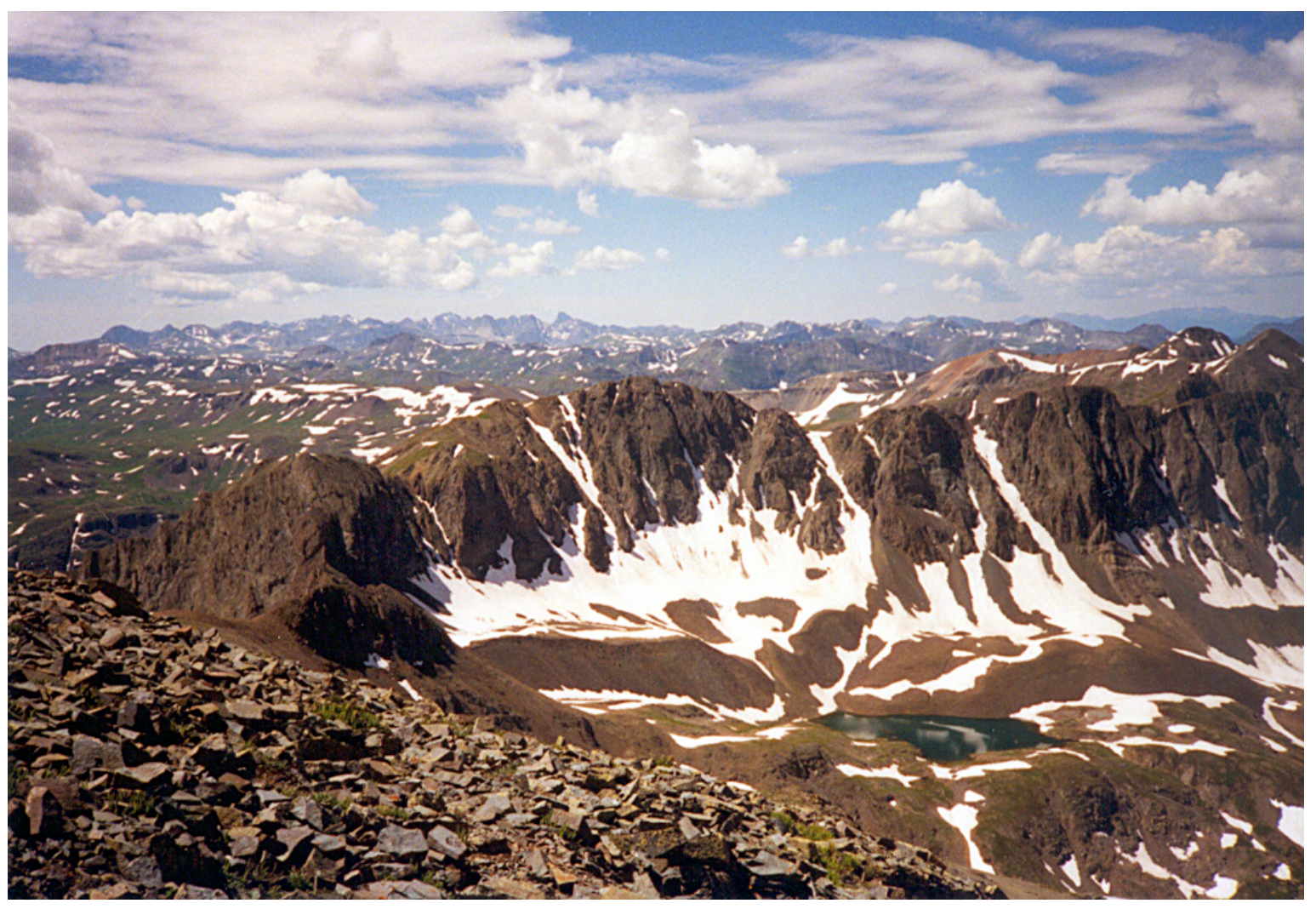

Fig. 2. Southwestward view of the American Basin Crags and San Juan Mountains from

Handies Peak in northwestern Hinsdale County. (Photograph by the author, August 1986.) 


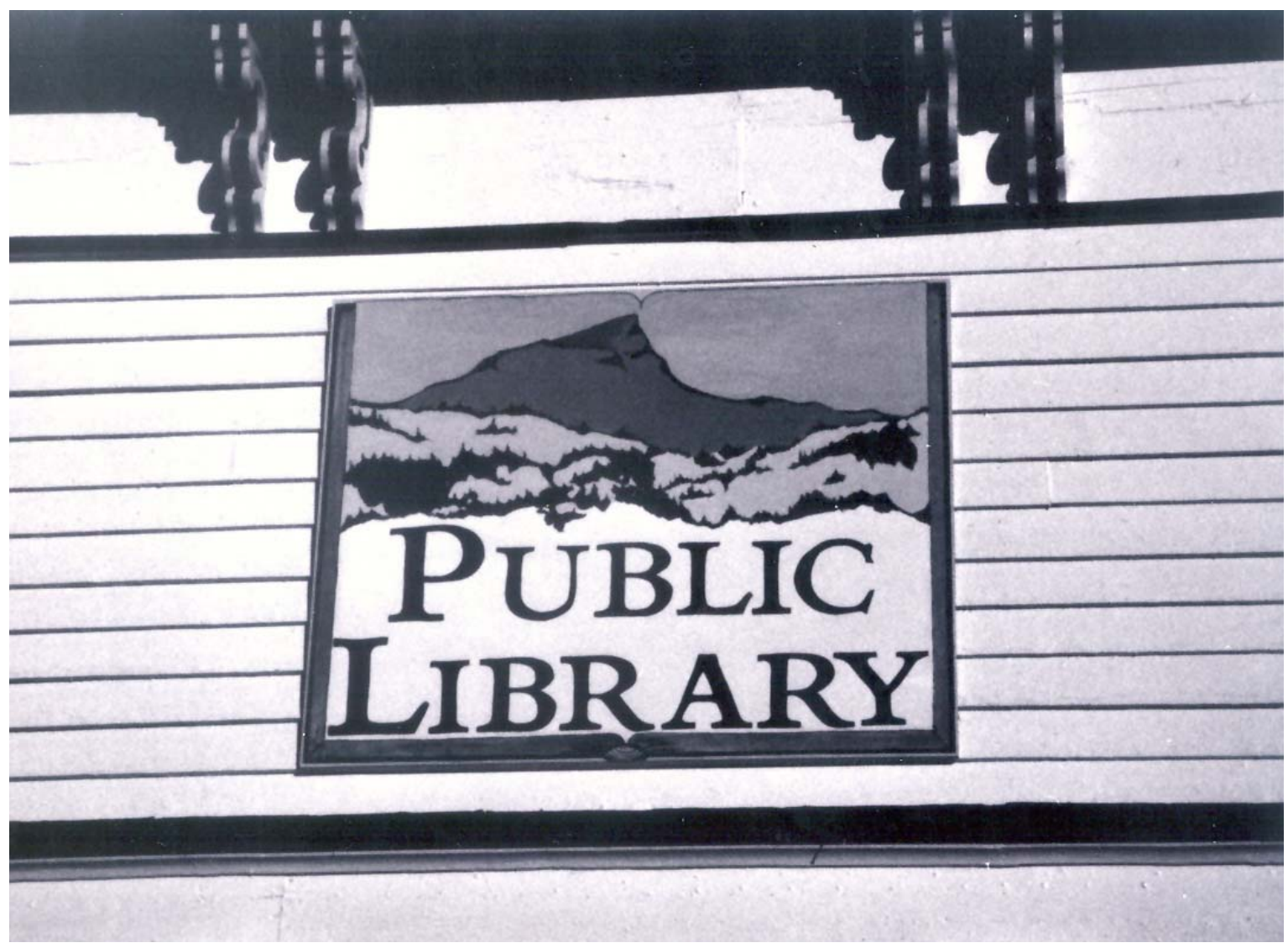

Fig. 3. Public library sign in Lake City with icon of Uncompahgre Peak (Photograph by the author, August 1993). 


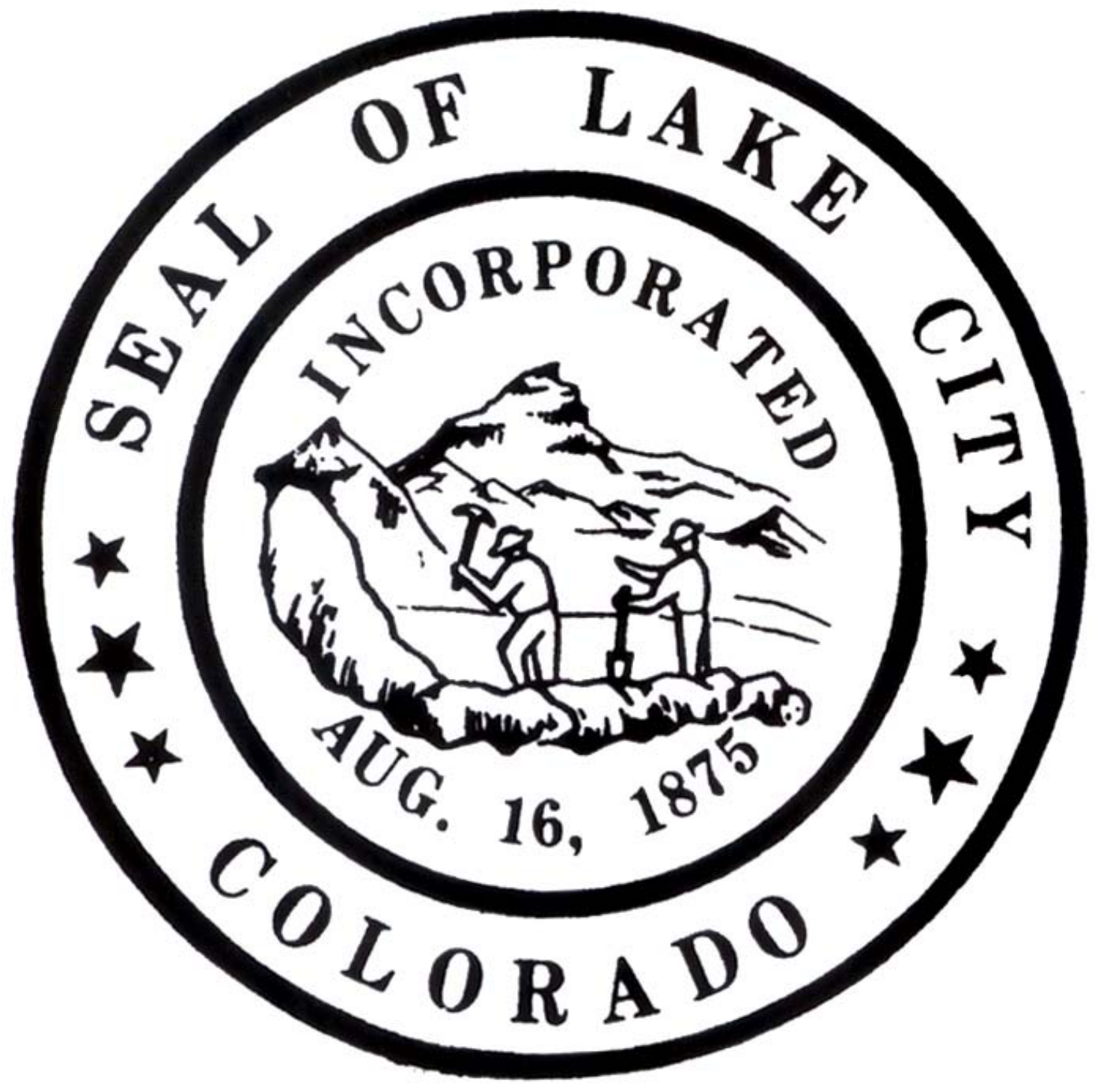

Fig. 4. Seal of Lake City with miners and a signature icon of Uncompahgre Peak.

(Reproduced from the collection of the author.) 


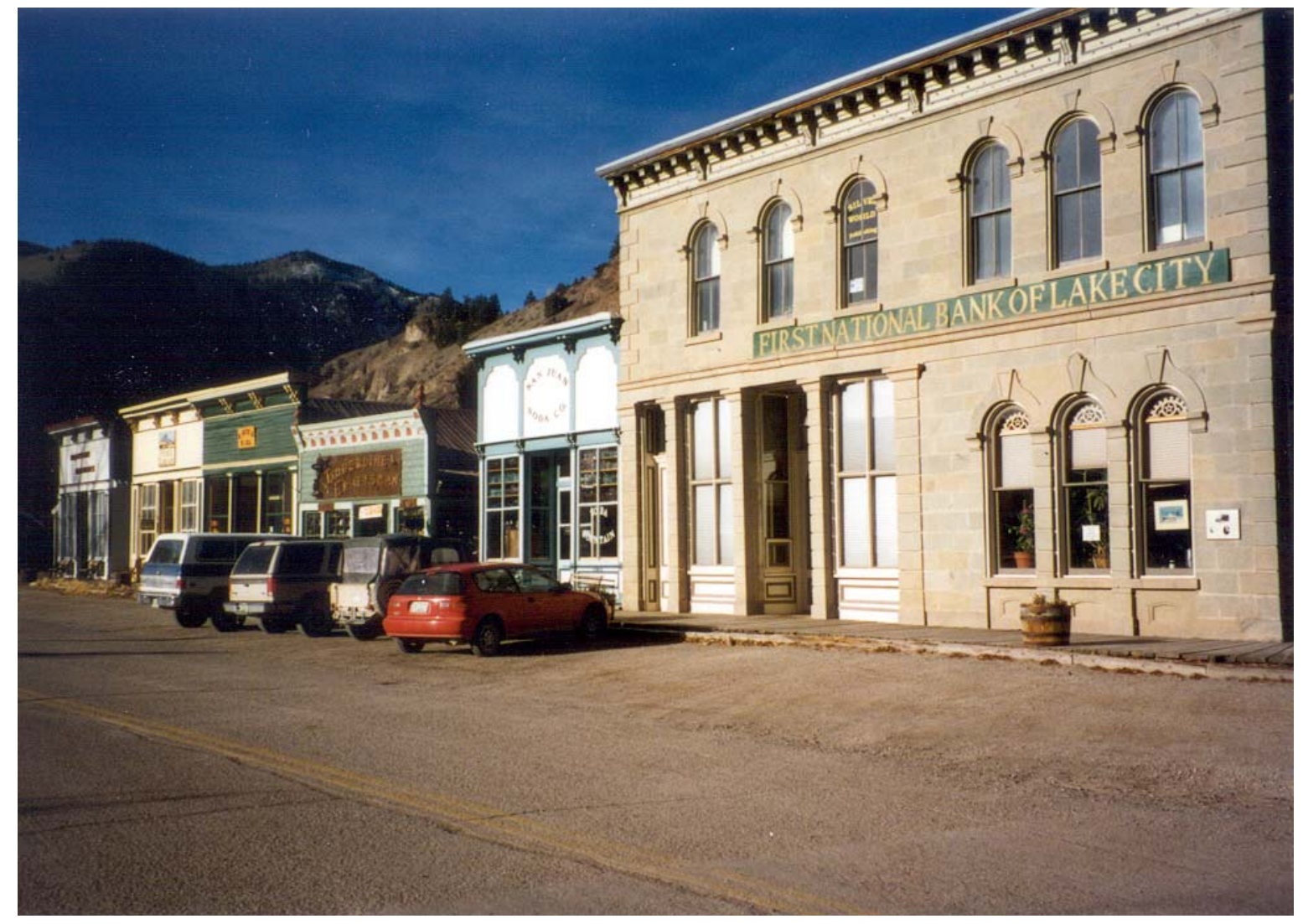

Fig. 5. Silver Street in downtown Lake City. (Photograph by the author, November 1995.) 


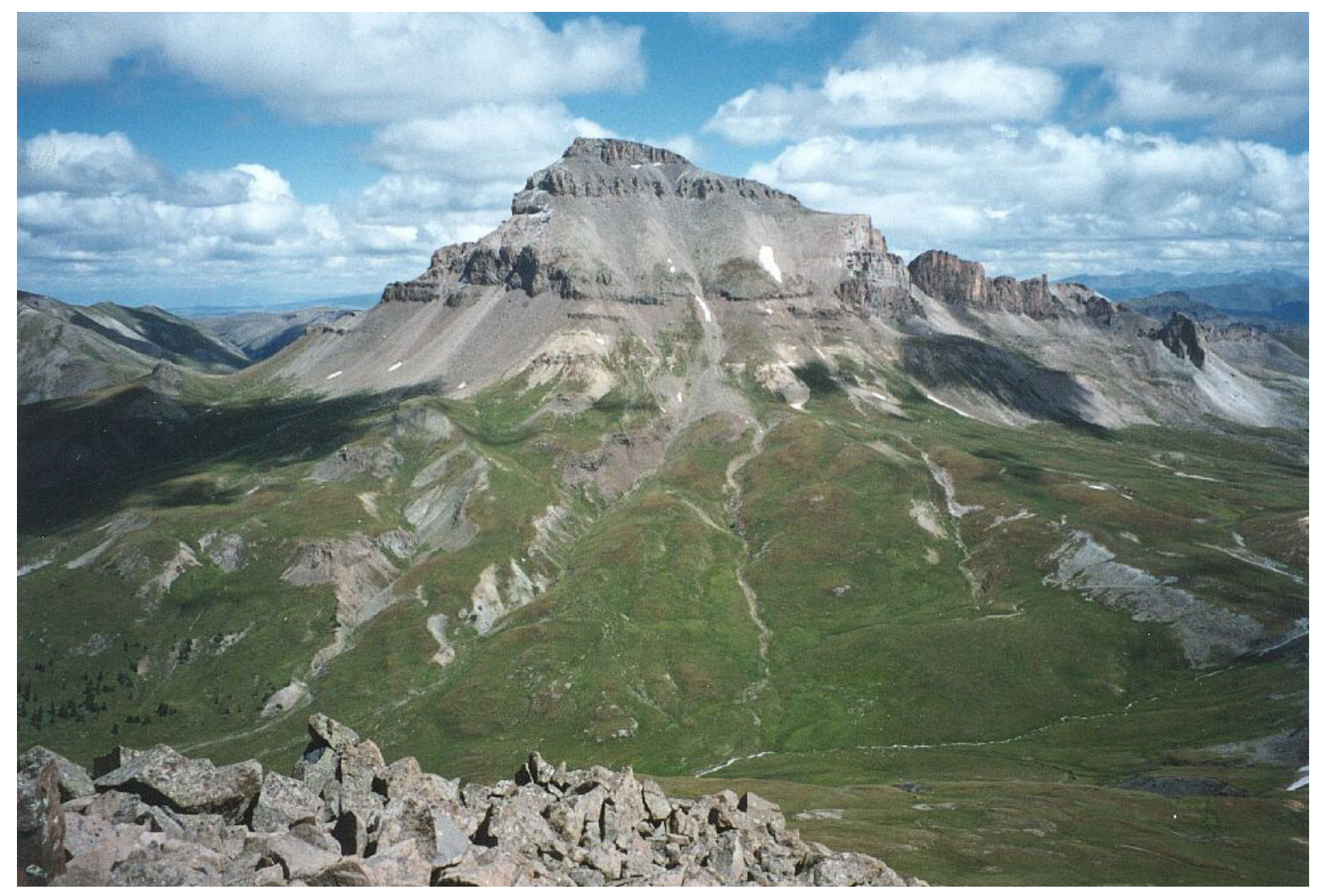

Fig. 6. Eastward view of the western slope of Uncompahgre Peak from Matterhorn Peak.

This view is opposite of that seen from the Lake City area and represented in Figures 3 and

4. (Photograph by the author, September 1995.) 


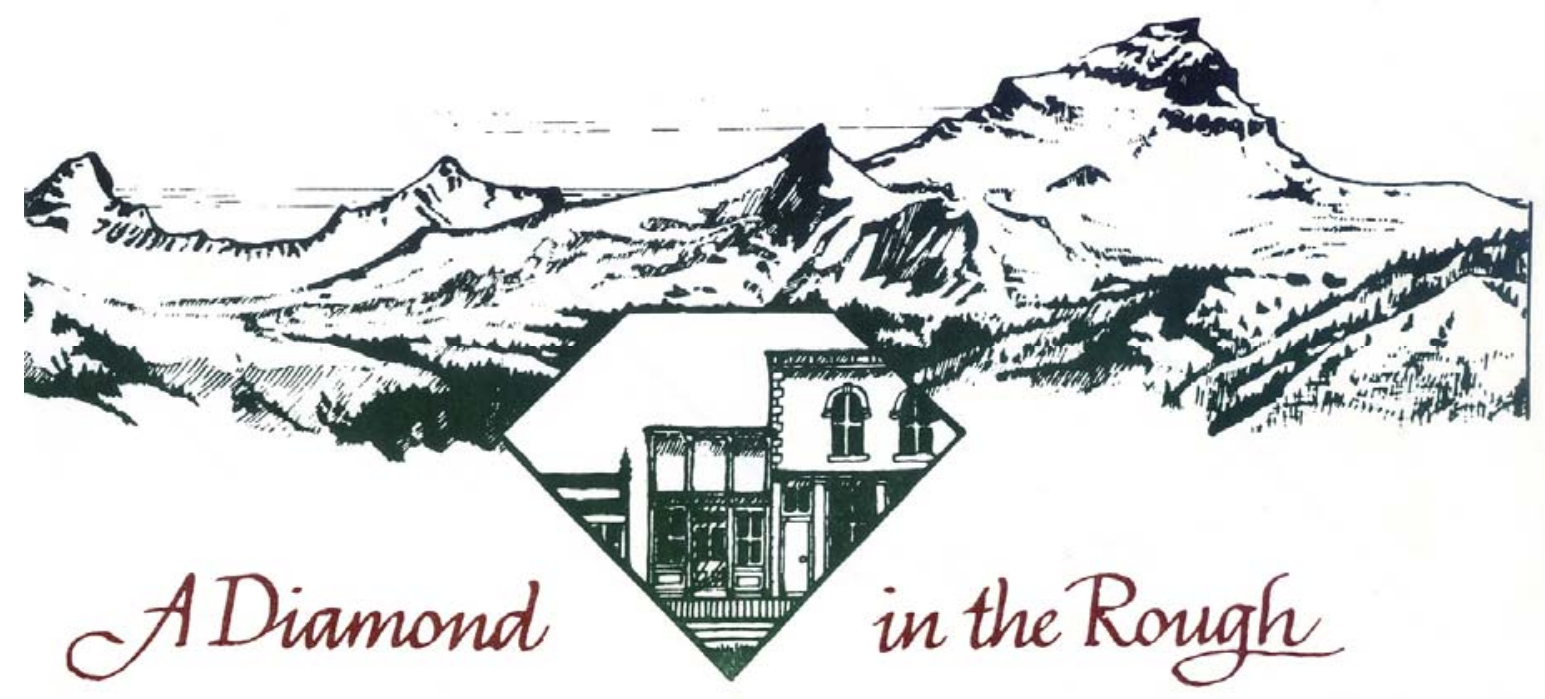

Fig. 7. Lake City-Hinsdale County Chamber of Commerce promotional logo in 1991. The mountain scene representation is the view from Windy Point Overlook on the west side of Slumgullion Pass on State Highway 149 seven miles southeast of Lake City. The buildings represented are on Silver Street in Lake City (compare with Fig. 4.). (Reproduced from the collection of the author.) 


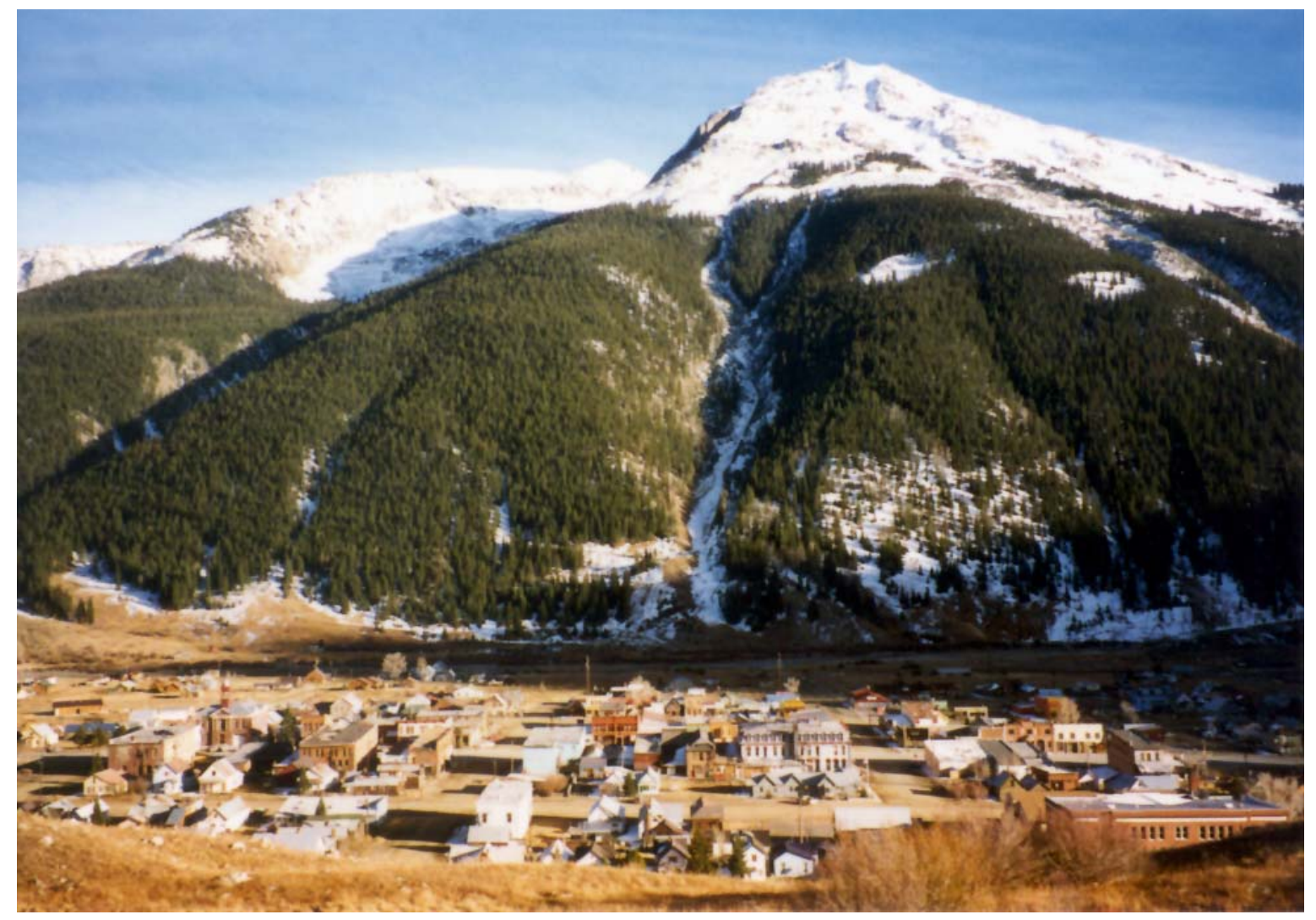

Fig. 8. Eastward view from Anvil Mountain of Silverton and Kendall Mountain, the town's peak of identity. An avalanche track runs down the west face of Kendall Mountain directly toward town. (Photograph by the author, November 1995.) 


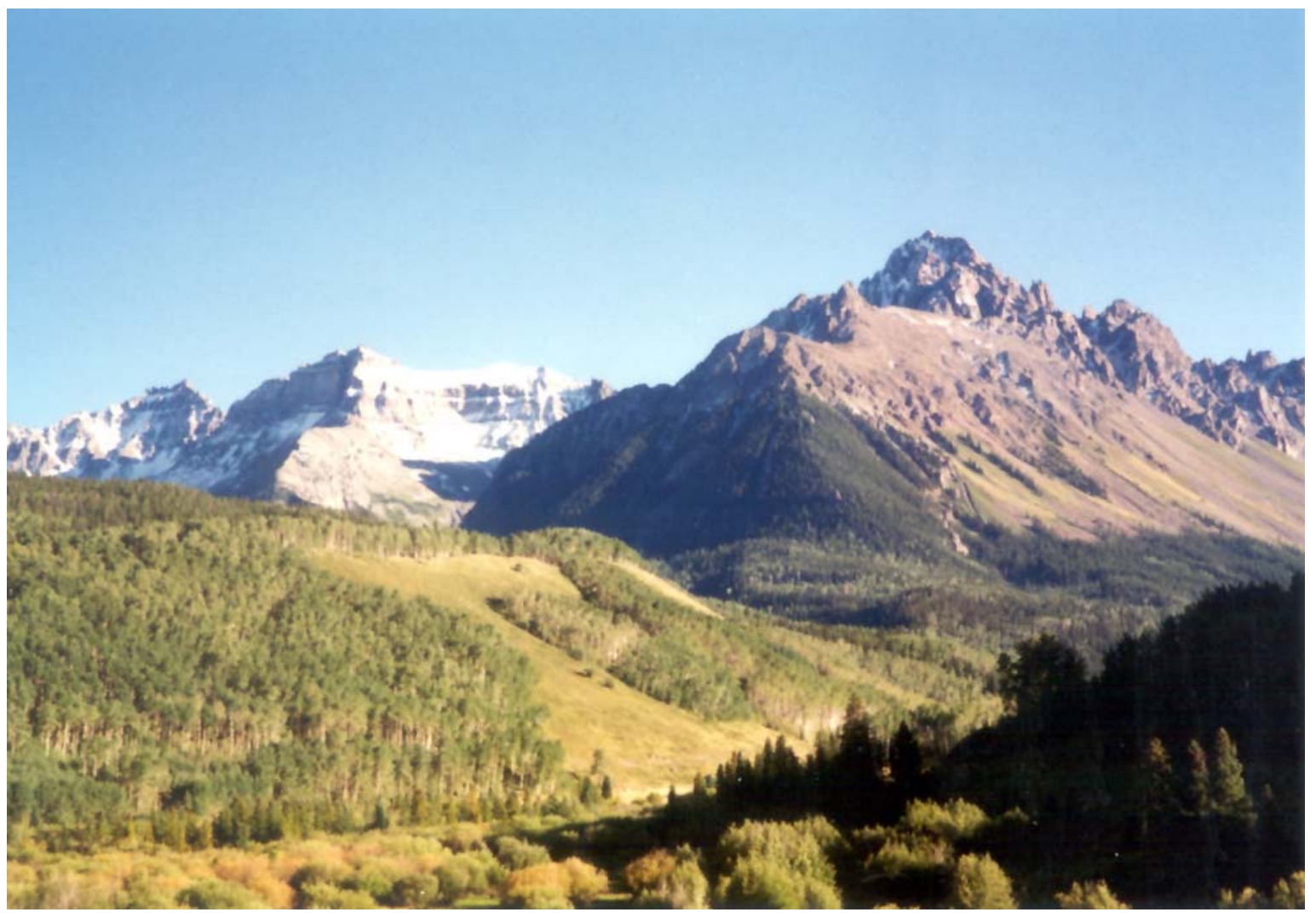

Fig. 9. Southward view of Mount Sneffels (right) from the East Fork Dallas Creek road.

(Photograph by the author, September 1995.) 


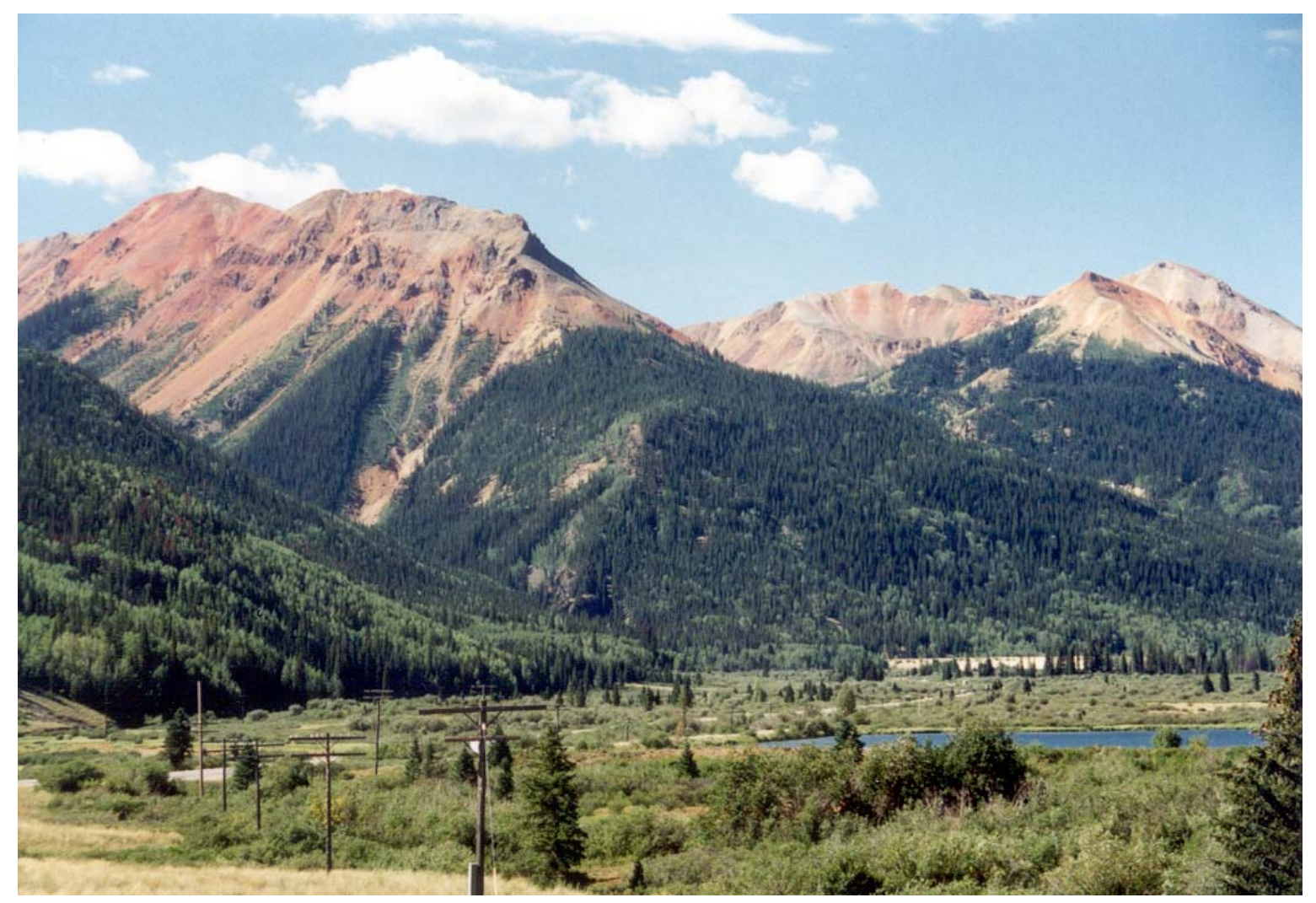

Fig. 10. Southward view of the Red Mountain summits from Ironton Park along the Million Dollar Highway (U.S. 550). (Photograph by the author, August 1994.) 